Józef POCHWAT MS

(Kraków)

\title{
WIARA I MĄDROŚĆ W ŚWIETLE KOMENTARZA PELAGIUSZA DO LISTU ŚW. PAWLA DO EFEZJAN*
}

Pelagiusz jest jednym $\mathrm{z}$ pierwszych, obok Mariusza Wiktoryna i Ambrozjastra, komentatorów listów św. Pawła Apostoła na Zachodzie. O nim samym historia niewiele nam przekazała informacji. Panuje powszechna opinia, że w młodym wieku wstąpił do klasztoru, a ojczyzną jego była Brytania ${ }^{1}$. Będąc człowiekiem dorosłym udał się do Rzymu. Żadne jednak źródła nie informują nas o przyczynach ${ }^{2}$, dla których Pelagiusz (w opinii większości badaczy) jako mnich ${ }^{3}$ miałby opuścić swoją ojczyznę. Nie jest również znana dokładna data jego przybycia do Rzymu; wśród historyków panują tu duże rozbieżności, choć przeważa opinia, że dotarł do stolicy Imperium za pontyfikatu papieża Damazego, czyli nie później niż w 384 roku. W Rzymie Pelagiusz oddawał się studiom i jako wykształcony mnich, dzięki znajomości teologii oraz języków łacińskiego i greckiego, zyskał sobie szacunek w kręgach rzymskiej arystokracji. Sam św. Augustyn, który był wówczas wielkim autorytetem w dziedzinie teologii, uznawał jego talent $\mathrm{i}$ zdolności, mimo iż

\footnotetext{
${ }^{*}$ Wyciąg z pracy magisterskiej pt. Wiara i madrość wedtug Komentarza Pelagiusza do Listu św. Pawła do Efezjan napisanej w 1986 r. w PAT pod kierunkiem ks. prof. dra hab. E. Stańka.

${ }^{1}$ Brytyjskie pochodzenie Pelagiusza poświadcza św. Augustyn w Liście 186 do Paulina (por. Ep. 186, 1, 1, PL 33, 816: „Britonem fuisse cognominatum”), gdzie nazywa go Brito; zob. też G. Bardy, Święty Augustyn, człowiek i dzieło, tłum. Z. Kobylańska, Warszawa 1955, 312; A. Nawrocki, Pelagiusz, Kraków 2006.

${ }^{2}$ P. Borniński (Pelagiusz, pelagianie, pelagianizm, w: Encyklopedia kościelna, t. 19, Warszawa 1893, 3) pisze, że powodem opuszczenia ojczyzny była chęć nawiedzenia miejsc świętych w Palestynie, lecz nie podaje źródła tej informacji; J. Umiński (Historia Kościoła, t. 1, Opole 1959, 216) podaje, że powodem było pragnienie zdobywania wiedzy.

${ }^{3}$ Przeważa opinia uznająca Pelagiusza za mnicha, por. m.in. W. Myszor, Wstęp, PSP 10, 7; J. Daniélou - H.J. Marrou, Historia Kościoła, thum. M. Tarnowska, Warszawa 1984, 298.

${ }^{4}$ B. Altaner (Patrologia, tłum. P. Pachciarek, Warszawa 1990, 497) pisze, że Pelagiusz przybył do Rzymu ok. 384 r., G. Bardy (Święty Augustyn, człowiek i dzieło, s. 9) natomiast, że między 375 a 380 rokiem.
} 
uważał jego naukę za heretycką i zwalczał pelagianizm, w czym brał udział także św. Hieronim ${ }^{5}$.

Pelagiusz prowadził tak ascetyczne życie, że uważano go w Rzymie za męża świątobliwego ${ }^{6}$. W okresie rzymskim spotkał prawnika Celestiusza, z którym w 410 r., w obawie przed wojskiem Alaryka, udał się do Afryki, a następnie stąd do Palestyny. Jego przyjaciel Celestiusz wraz z uczniami pozostał jednak w Afryce, gdzie głosił naukę Pelagiusza i pod jego nieobecność wszczynał spory, siejąc niepokój w Kościele afrykańskim. Wynikiem tych sporów było potępienie przez Kościół afrykański w Kartaginie tez pelagiańskich ${ }^{7}$, potwierdzone później przez papieża Innocentego I. Ale już w 415 r. na synodzie w Diospolis Pelagiusz został uniewinniony, a nowy papież Zozym (417-418), po zwołaniu dwóch synodów w Rzymie, zrehabilitował zarówno Pelagiusza jak i Celestiusza. To posunięcie papieża spotkało się z wielkim oburzeniem ze strony biskupów Afryki. Po ich gwałtownej interwencji, papież Zozym w roku 418 w encyklice Epistula tractoria potępił pelagianizm ${ }^{8}$.

O ile pełniejsze opracowanie biogramu Pelagiusza uniemożliwia znikoma ilość zachowanych danych biograficznych, o tyle brak danych odnośnie nauki Pelagiusza, jest jeszcze bardziej dotkliwy ${ }^{9}$, co z kolei uniemożliwia prezentację całokształtu jego myśli teologicznej. Niniejszy artykuł stanowi próbę przedstawienia dwóch aspektów (wiara - mądrość) nauki Pelagiusza na

${ }^{5}$ Św. Augustyn (Liber de natura et gratia VI 6) i św. Hieronim (Dialogus contra Pelagianos III 16 oraz Ep. 50,3) określają Pelagiusza jako homo latinissimus et facundissimus, choć ten ostatni nazywa (Prologus in commentarium in Jeremiam prophetam, PL 24, 706A) go również indoctus calumniator.

${ }^{6}$ Por. Bardy, Święty Augustyn, człowiek i dzieło, s. 314; S. Szydelski, Indywidualność św. Augustyna, Włocławek 1931, 23.

${ }^{7}$ Por. Mansi IV 290-292; Hefele-Leclercq II/1, 168 i 180.

${ }^{8}$ Por. Zosimus, Epistula tractoria, PL 20, 693-702. Spotykamy zatem dwie różniące się od siebie opinie w orzeczeniach tego samego papieża Zozyma, sprzeczność jednak znika, jeśli odróżni się potępienie nauki od potępienia kogoś, kto faktycznie głosi naukę potępioną. W tym miejscu trafne wydaje się odróżnienie tez Pelagiusza od tego, co ogólnie nazywa się pelagianizmem, a do których wypracowania przyczynił się nie tylko on sam, lecz także Celestiusz i Julian z Eklanum, zob. E. Florkowski, Soteriologia Pelagiusza, Kraków 1949, 5.

${ }^{9}$ W Katedrze Patrologii i Historii Dogmatu PAT w Krakowie pod kierunkiem ks. prof. E. Stańka, który habilitował się na podstawie rozprawy: Usprawiedliwiający charakter wiary. Studium porównawcze „Komentarzy do Listów św. Pawła” Ambrozjastra i Pelagiusza, powstały następujące prace magisterskie mające związek z Pelagiuszem i jego doktryną: T. Cichoń, Stosunek papieża Zozyma do pelagianizmu, Kraków 1982; W. Kubasiak, Poczatki pelagianizmu według Commonitorium super nomine Caelestii Mariusza Merkatora, Kraków 1982; A. Baron, Ideat duszpasterza. Studium w oparciu o Komentarz Pelagiusza do Listu do Tytusa, Kraków 1985; J. Pochwat, Wiara i madrość wedtug Komentarza Pelagiusza do Listu św. Pawła do Efezjan, Kraków 1986; W. Gołaski, Wykład o wierze, charyzmatach i miłości w Komentarzach Ambrozjastra i Pelagiusza do 12 i 13 rozdziału I Listu św. Pawła do Koryntian. Studium porównawcze, Kraków 1993 - podaję za: Wielcy Kaznodzieje Krakowa. Studia in honorem prof. Eduardi Staniek, red. K. Panuś, Kraków 2006, s. XII-XXX. 
podstawie jego Komentarza do Listów św. Pawła, pisanego w Rzymie w latach 406-409 ${ }^{10}$. Komentarz ten zawiera objaśnienia do poszczególnych zdań z Listów św. Pawła ${ }^{11}$, z wyjątkiem Listu do Hebrajczyków. Interesuje nas tutaj nauka Pelagiusza w aspekcie wiary i mądrości, przedstawiona w Komentarzu do Listu św. Pawła do Efezjan. Zanim jednak przejdziemy do głównego tematu przynajmniej pokrótce przypomnimy ważniejszą literaturę pelagiańską, ze szczególnym uwzględnieniem pozycji dotyczących Komentarza do Listów św. Pawta. Badania wybitnych patrologów: H. Zimmera, C.H. Turnera, E. Riggenbacha, G. Mercatiego, S. Helmanna, G. Morina, a zwłaszcza A. Soutera, doprowadziły do ustalenia autentycznego brzmienia tekstu tego Komentarza ${ }^{12}$. A. Souter zakończył swe badania wydaniem krytycznego tekstu ${ }^{13}$, który stanowi podstawę dla niniejszego artykułu. Zdecydowana większość publikacji o tym Komentarzu dotyczy w zasadzie problemów autorstwa i autentyczności tekstu. Wprawdzie istnieją ogólne i syntetyczne opracowania Komentarza autorstwa R.F. Evansa, G. Plinvala i A. Soutera, ale prawie w ogóle nie ma opracowań jego treści.

Na przestrzeni ostatnich pięćdziesięciu lat pojawiło się w literaturze światowej kilka obszerniejszych opracowań dotyczących teologicznego dorobku Pelagiusza ${ }^{14}$. W języku polskim, jak dotąd, ukazały się zaledwie dwie cytowane już prace przybliżające teologię Pelagiusza: Nauka chrystologiczna Pelagiusza ks. Mariana Michalskiego oraz studium historyczno-dogmatyczne Soteriologia Pelagiusza ks. Eugeniusza Florkowskiego: ten pierwszy cytuje kilka razy Komentarz do Listu do Efezjan, zaś drugi kilkanaście. W „Studia Gnesnensia” w 1980 r., ukazał się artykuł Nad geneza teologii Pelagiusza ks. Szczepana Pieszczocha, w którym autor konkluduje swoje wywody w następujący sposób: „Artykuł niniejszy zestawia dane określające sylwetkę duchową Pelagiusza na tle sytuacji religijnej w Rzymie w IV wieku, specyfikę jego działalności literackiej i nauczycielskiej, zależności literackie i doktrynalne,

${ }^{10}$ Por. Florkowski, Soteriologia Pelagiusza, s. 7, n. 2 oraz M. Michalski, Nauka chrystologiczna Pelagiusza, Kraków 1936, 145.

${ }^{11}$ Przyjmuje się, że Autor posłużył się przy komentowaniu tekstem natchnionym z końca IV wieku w wersji Vetus Latina, por. Sz. Pieszczoch, Nad geneza teologii Pelagiusza, SG 5 (1979-1980) 228.

${ }^{12}$ Por. Florkowski, Soteriologia Pelagiusza, s. 7.

${ }^{13}$ Por. Pelagii Expositiones XIII Epistularum Pauli, ed. A. Souter: Pelagius's Expositiones of thirteen Epistles of St. Paul. Text and apparatus criticus (Text and Studies contributions to biblical and patristic Literature, vol. IX 2), Cambridge 1926, 344-386, przedruk PLS 1, 1110-1374.

${ }^{14}$ Por. T. Bohlin, Die Theologie des Pelagius und ihre Genesis, Uppsala - Wiesbaden 1957; H. Esser, Das Paulus Verständnis des Pelagius nach seinem Pauluskommentar, Bonn 1961; R.F. Evans, Pelagius, New York 1968; J. Ferguson, Pelagius, Cambridge 1978; G. Greshake, Grade und konkrete Freiheit: eine Untersuchung zur Gnadenlehre des Pelagius, Mainz 1972; R. Pirenne, La morale de Pelage, Roma 1961; S. Prete, Pelagio et il pelagianismo, Brescia 1961; O. Wermelinger, Pelagius und Rom, Stuttgart 1975, a także niewielki artykuł G. Bonnera, How Pelagian was Pelagius, StPatr 9 (1966) 350-358. 
jego znajomość Pisma Świętego, wreszcie okoliczności, które wpłynęły na rozpoczęcie kontrowersji pelagiańskiej" 15 .

W ostatnich latach zwracają uwagę wnikliwe opracowania teologii Komentarza do Listu do Rzymian ${ }^{16}$ i do Tytusa ${ }^{17}$ ks. Arkadiusza Barona. Konkludując zauważa on, że omówienie literatury pelagiańskiej nie nastręcza szczególnych problemów, natomiast pisma Pelagiusza prezentują wysoki już stopień trudności ${ }^{18}$. W Komentarzu Pelagiusza do Listu do Efezjan cnoty: wiara i mądrość stanowią główny element jego wykładu nauki św. Pawła. W zasadzie Pelagiusz traktuje wiarę jako fundament, zaś mądrość jako budynek wznoszący się na tym fundamencie.

1. Usprawiedliwiający dar wiary. Dla Pelagiusza wiara to dar, czyli łaska pochodząca od Boga ${ }^{19}$. Koncepcja wiary, w ujęciu Autora, oparta jest na dobrej woli człowieka ${ }^{20}$. Widać tu zatem wyraźnie dwa istotne elementy: działanie Boga, który daje łaskę darmo, i odpowiedź człowieka, która oparta jest na wolnej woli człowieka. Dzięki temu człowiek wchodzi w kontakt z Bogiem, staje się Jego przybranym synem i przynależy do Jezusa Chrystusa - naturalnego Syna Bożego ${ }^{21}$.

Pelagiusz łączy wiarę bezpośrednio z usprawiedliwieniem człowieka. Tym, który dokonuje usprawiedliwienia jest Chrystus ${ }^{22}$. To usprawiedliwienie człowieka polega na przejściu od świata do Boga, od grzechu do łaski, od szatana do Chrystusa; zatem usprawiedliwienie człowieka złączone jest ściśle

\footnotetext{
${ }^{15}$ Pieszczoch, Nad genezq teologii Pelagiusza, s. 228.

${ }^{16}$ Por. A. Baron, Spór o Pawła, spór o człowieka czy spór o Boga: refleksje na marginesie kontrowersji pelagiańskiej, w: Pelagiusz, Komentarz do «Listu św. Pawła do Rzymian», ŹMT 15, Kraków 1999, 6-116.

${ }^{17}$ Por. A. Baron, Lacińskie komentarze do listu do Tytusa (Ambrozjaster, Hieronim, Pelagiusz) na tle recepcji myśli Pawłowej w starożytności, ŹMT 28, Kraków 2003, 9-106.

${ }^{18}$ Por. A. Baron, Spór o Pawła, s. 22-23.

${ }^{19}$ Pelagiusz komentując słowa św. Pawła: „Qui praedestinavit nos in adoptionem” dodaje (In epistolam ad Ephesios 1, 5, ed. A. Souter, s. 345, PLS 1, 1289): „Non naturae”; por. Florkowski, Soteriologia Pelagiusza, s. 140: „Ale wspomina też o darmowym wezwaniu do wiary i zbawienia (za pomocą nauki objawionej) oraz o możności otrzymania od Boga «ducha wiary», o ile człowiek tego chce".

${ }^{20}$ Por. In epistolam ad Ephesios 1, 5, ed. Souter, s. 345-346 lub PLS 1, 1289. „Hoc praedestinavit, ut haberent potestatem Filius Dei fieri omnis qui credere voluissent, sicut scriptum est: «loquebantur verbum Dei cum fiducia omni volenti credere». Ut membra eius simus. Non secundum merita nostra”; zob. Florkowski, Soteriologia Pelagiusza, s. 132-133, spec. 149: „Samą wiarę, będącą warunkiem usprawiedliwienia i zbawienia, uważa Pelagiusz za dzieło wolnej woli”.

${ }^{21}$ Por. In epistolam ad Ephesios 5, 1, ed. Souter, s. 372 lub PLS 1, 1302: „Imitatione enim natura, non natura filii Dei sumus, sicut ait Salvator: «ut sitis filii Patris vestri qui in caelis est»".

${ }^{22}$ Por. tamże 2, 8-9, ed. Souter, s. 353 lub PLS 1, 1293: „Non meritis prioris vitae, sed sola fide, sed tamen non sine fide. Se suis meritis aliquit in baptismo accepisse"; tamże 2, 15, ed. Souter, s. 355 lub PLS 1, 1294: „Per solam fidem iustificans et mortalia sola decernens”; zob. Florkowski, Soteriologia Pelagiusza, s. 127-131 i 149.
} 
ze chrztem ${ }^{23}$. Autor uważa, że warunkiem przejścia z niewiary do Boga jest uwierzenie w Chrystusa. Twierdzi, że niewierzący są pod wpływem szatana i błądzą w ciemnościach ${ }^{24}$.

Zdaniem Pelagiusza, wiara gładzi grzechy ${ }^{25}$ i potrzebna jest do przyjęcia chrztu. Wiara jest zatem warunkiem zbawienia ${ }^{26}$. Uważa, że dostąpić usprawiedliwienia może każdy, kto uwierzy w Chrystusa, w zbawczą moc Jego krzyża $^{27}$, czyli w wyzwolenie płynące $\mathrm{z}$ wiary w zbawczą moc męki Jezusa ${ }^{28}$. Według Pelagiusza wiara wprowadza na drogę zbawienia ${ }^{29}$, a zbawczą rolę wiary ujawnia obecność Jezusa Chrystusa w duszy człowieka wierzącego. Dla podkreślenia ważności chrztu wskazuje, iż w nim dokonuje się zrodzenie z Boga $\mathrm{Ojca}^{30}$. Z tym szczególnym pochodzeniem człowieka wierzącego wiąże się jego powołanie do życia bez grzechu. Pelagiusz podkreśla, że chrzest powoduje uświęcenie ludzi wierzących i wyciska w nich znamię Ducha Swiętego ${ }^{31}$.

\footnotetext{
${ }^{23}$ Por. In epistolam ad Ephesios 1, 1, ed. Souter, s. 344 lub PLS 1, 1289: „Omnes sancti fideles, non omnes fideles sancti, quia possunt etiam catechumini, ex eo quod Christo credunt, fideles dici, non tamen sancti sunt, quia non sunt per baptismum sanctificati. Sive: Sic intellegendum quod scribat fideliter servantibus sanctitatis".

${ }^{24}$ Por. tamże 2, 3, ed. Souter, s. 352 lub PLS 1, 1292: „Non solum vos gentes non credendo, sed et nos Iudaei peccando [...]. Quando mens nostra rebus terrenis et carnalibus inhaerebat, non solum desiderans, sed et faciens quaecumque mala cogitatio suggessisset"; tamże 2, 2, ed. Souter, s. 351: „Notandum quod in peccatis ambulasse, non «ambulare», illos dixerit [...]. Saeculi hominibus similes, sequentes diaboli voluntatem [...]. Secundum principem illius potestatis, quae in hoc aere ventoso est. Multi sane opinantur quod diabolus in hoc aere satellitibus suis ad decipiendos diversis peccatis homines diviserit potestatem. Operatur suasione, non vi [...]. In eos qui non credunt: illi autem qui desperant atque diffidunt de promissione Dei, dicuntur filii diffidentiae, sicut filii irae et gehennae et mortis".

${ }^{25}$ Por. tamże 1, 7, ed. Souter, s. 346 lub PLS 1, 1289: „Non solum redemit, sed etiam peccata remittens sine nostro labore iustos nos fecit".

${ }^{26}$ Por. tamże 3, 11-12, ed. Souter, s. 359 lub PLS 1, 1296: „Qua praefinivit ut hoc tempore, quando iam aliter homines salvari non poterant, sola Christi fide salvarentur [...]. Non per nostram iustitiam, sed per eum cuius fides nobis peccata dimisit".

${ }^{27}$ Por. tamże 2, 16, ed. Souter, s. 355 lub PLS 1, 1294: „Per solam fidem crucis, quae nullum deterret: non enim gravis aut difficilis est, quam habere etiam latro potuit cruci fixus".

${ }^{28}$ Por. tamże 2, 13, ed. Souter, s. 354 lub PLS 1, 1293: „Credendo vos eius sanguine et passione liberatos".

${ }^{29}$ Por. tamże 2, 5, ed. Souter, s. 352 lub PLS 1, 1293: „Sine peccato, sicut Christus est, per baptismum faciendo. Propter ipsum. Sive: Qui pro vobis gratis in Christo, nullo iustitiae vestro merito intercedente, est mortuus, vel cum ipse reus non esset".

${ }^{30}$ Por. tamże 4, 5, ed. Souter, s. 363 lub PLS 1, 1297: „Unde diligentibus legere deberent hunc locum hii qui saeculi occupationibus inligati putant sibi licere peccare et aliis non licere, cum omnes in unum corpus baptizati spiritum eundem acceperint et in una spe vocati sint Dei. [Sive sic]: Si unum spiritum habetis et ex uno Patre Deo nati estis, nolite vobis de terrena nobilitate aliquit adrogare, ne veram gloriam amittatis".

${ }^{31}$ Por. tamże 4, 30, 371 lub PLS 1, 1301: „Hominibus loquens comparationes inducit humanas, ut ex nobis intellegamus quantam Spiritui Sancto iniuriam faciamus, cum domum eius in nobis
} 
Celem wiary jest, zdaniem Autora, oddawanie chwały Bogu: kto wierzy, wielbi prawdziwego Boga ${ }^{32}$. Pelagiusz przestrzega przed utratą wiary ${ }^{33}$, bowiem wiara, jako conditio sine qua non zbawienia, zakłada nieodzowność życia z wiary. Dobre uczynki i prawe postępowanie na wzór synów Bożych są istotne przy osiąganiu zbawienia.

Pelagiusz nie popełnia błędu, gdy uczy, iż sama wiara wystarczy do zbawienia, a potem - że koniecznym do tego warunkiem są także dobre uczynki. Gdy zaś uczy o zbawieniu otrzymanym darmo, przez samą tylko wiarę, ma na myśli usprawiedliwienie, w którym dokonuje się odpuszczenie grzechów. Gdy natomiast mówi o potrzebie dobrych uczynków i należytego postępowania według wskazań Ewangelii, ma na myśli zbawienie, przez które osiąga się Królestwo niebieskie, czyli zbawienie wieczne ${ }^{34}$. Oprócz tego Pelagiusz wiąże ściśle cnotę wiary z cnotą miłości ${ }^{35}$, uważając, że ta pierwsza bez miłości jest bezowocna.

Pelagiusz uczy, że przez chrzest człowiek staje się członkiem Kościoła. Jak w każdej społeczności, tak i w tej, jednostka jest odpowiedzialna za całość, a całość za jednostkę. Autor uzależnia doskonałość Kościoła od doskonałości wiary każdego z Jego członków ${ }^{36}$ : wiara poszczególnych wiernych decyduje zatem o pełni doskonałości całego Kościoła, a wartość poszczególnych jednostek rzutuje na całą społeczność. Dlatego też wierzący są odpowiedzialni za wiarę swoją i innych. Pelagiusz wzywa zatem wierzących do posługiwania się nawet mową tak, by wpływała ona na rozwój wiary wszystkich ludzi ${ }^{37}$.

aliqua peccati sorde polluimus, et quia de hospitio suo nobis condolens, non sibi dolens, tristis abscedat".

${ }^{32}$ Por. tamże 1, 12, ed. Souter, s. 347-348 lub PLS 1, 1290: „Ut per conversationem nostram, sive per signa quae facimus, laudetur gloria Dei. Nos apostoli vel Iudaei, qui priores credidimus in Christo. Sive: Ex lege expectavimus Christum".

${ }^{33}$ Pelagiusz uważa (por. tamże 1, 15, ed. Souter, s. 348 lub PLS 1, 1291), że wiara może być narażona na zgubę przez działanie złych proroków i złych duchów: „Et omnes bonos sine exceptione personae vel notitiae diligatis: cavere enim a pseudo-prophetis et non omni spiritui credere et non ante probationem nobis iudicare praecipitur"; albo przez złą mowę (por. tamże 4, 29, ed. Souter, s. 370 lub PLS 1, 1301: „Non unus nec duo, sed omnes mali sermones in ore Christiani debent esse cruci fixi”; albo puste słowa (por. tamże 5, 6, ed. Souter, s. 374 lub PLS 1, 1302): „Quae hominem liberare non poterunt"; czy nieodpowiednie postępowanie ludzi wierzących (por. tamże 5, 15, ed. Souter, s. 375 lub PLS 1, 1303): „Quasi filii sapientiae et lucis, ne alicui offendiculum detis et incipiatis ei causa perditionis existere".

${ }^{34}$ Do podobnych wniosków dochodzi E. Florkowski (Soteriologia Pelagiusza, s. 127-128, spec. s. 133-136).

${ }^{35}$ Por. In epistolam ad Ephesios 6, 23, ed. Souter, s. 386 lub PLS 1, 1308 :,,Pax et caritas et fides perfectum faciunt Christianum: tam enim sine fide infructuosa est caritas, quam fides sine caritate vel pace. Nam caritas maior est pace: potest enim odio non haberi quis, non tamen et amari".

${ }^{36}$ Por. tamże 1, 22-23, ed. Souter, s. 350-351 lub PLS 1, 1292: „Ecclesia omnium plenitudo membrorum. Quando omnes crediderint, tunc erit corpus eius perfectum in omnibus membris: totus enim in membris omnibus, non in singulis, adimpletur, ne nulla sit diversitas meritorum".

${ }^{37}$ Por. tamże 4, 29, ed. Souter, s. 371 lub PLS 1, 1301: „Hoc est quod alibi dicit: «sermo vester in gratia sit sale conditus», ut ex sermone nostro gratiam accipiant audientes". 
Domaga się też od wierzących apostolstwa poprzez dobry przykład, szczególnie zaś pracowitości i posłuszeństwa. Uważa bowiem, że taka postawa wzywa innych do wiary, czyli przyczynia się do jej rozszerzania ${ }^{38}$. Ponadto zaznacza, że w Kościele są ustanowieni przełożeni, którzy niejako z urzędu mają prowadzić innych do doskonałości wiary ${ }^{39}$, mówiąc zaś o społecznym charakterze wiary, troszczy się o jedność w jej wyznawaniu i uważa ją za źródło i zasadę jedności.

2. Mądrość buduje na wierze. Pelagiusz precyzując pojęcie mądrości, osadza ją na fundamencie wiary i miłości. Mądrość, według niego, może posiąść od Boga ten, kto posiada wyżej wymienione cnoty ${ }^{40}$. Mówiąc o mądrości jako darze Boga, zakłada posiadanie przez człowieka mądrości naturalnej, przez którą rozumie używanie rozumu. Podobnie jak wiarę, tak i mądrość uważa za dar pochodzący od Ojca. W mądrości Pelagiusz dostrzega pełnię chrześcijaństwa i dlatego uważa, że powinna ona obejmować wszystkie dziedziny życia ludzkiego, dzięki czemu człowiek może doskonalić wszystkie cnoty. Opierając mądrość na fundamencie wiary twierdzi, że decyduje ona o posiadaniu innych cnót i nazywa ją matką wszystkich cnót.

Według Komentatora mądrość pozwala poznać Boga i tworzy harmonię życia moralnego ${ }^{41}$. Mądrość daje wyższy stopień poznania woli Boga, wyższy niż ten, który daje wiara. Przez wyższe poznanie woli Boga rozumie on poznanie wielkości i mocy Bożej. Dzięki łasce mądrości człowiek dysponuje kryterium wartości, które jest czynnikiem nieodzownym do dobrego i prawego postępowania w życiu. Stąd też, według Pelagiusza, cnota mądrości daje znajomość i wiedzę potrzebną do rozróżniania między dobrem a złem. Autor wyraźnie stwierdza, iż wolę Pana znają tylko wierzący i oni są uzdolnieni do

${ }^{38}$ Por. tamże 6, 5, ed. Souter, s. 380 lub PLS 1, 1305.

${ }^{39}$ Pelagiusz podkreśla (tamże 4, 11, ed. Souter, s. 364-365 lub PLS 1, 1298), że sam Chrystus powołał różnych ludzi, by prowadzili członków Kościoła do doskonałości wiary: „Contra Arrianos, ut Filii et Patris una sit operatio: nam ad Corinthios Deum Patrem dicit istos in Ecclesia ordinasse, hic vero Christum hos dedisse commemorat [...]. Omnis apostolus evangelista, non omnis evangelista apostolus, sicut «Philippus, qui unus erat ex septem» (Acta 21, 8). Pastores sunt sacerdotes, doctores vero omnes qui sunt idonei ad alios instruendos. Omnis ergo pastor doctor, non omnis qui doctor, et pastor".

${ }^{40}$ Por. tamże 1, 17, ed. Souter, s. 349 lub PLS 1, 1291: „Notandum quia fidem et caritatem habentibus sapientiam a Domino deprecatur: noverat enim eam matrem omnium esse virtutum”.

${ }^{41}$ Por. tamże: „Quo modo optat ut agnoscant Deum, quem usque adeo noverant, ut ei credentes omnes propter ipsum diligent sanctos? sed hoc petit ut perfecte cognoscant magnitudinem eius atque virtutem; virtutem quia potest promissa praemia vel poenas implere, magnitudinem, quia, cum ubique sit, nihil eum potest omnino latere: qui enim hoc pro certo cognoverit, nullo poterit in loco peccare; nam qui humanum testimonium erubescit, multo magis divinum poterit revereri”. 
poznawania ukrytej tajemnicy woli Bożej, polegającej na odkrywaniu wielkości wiedzy ${ }^{42}$, którą mogą posiąść ludzie dobrzy i święci ${ }^{43}$.

Pelagiusz stwierdza, że poznanie Boga rzutuje na doskonałość życia moralnego człowieka, stąd też poszerza poznawczy charakter mądrości. Wyróżnia także poznawczy aspekt wiary pisząc, że światłość związana jest z poznaniem i że wiara czyni człowieka światłością. Niewierzący zaś żyje w stanie niewiedzy i musi najpierw powstać z grzechu i błędnej nauki, aby stać się światłością, czy też dostąpić oświecenia ${ }^{44}$. Równocześnie i mądrość przyrównuje nasz Autor do światłości, która daje poznanie Boga w Jego istnieniu ${ }^{45}$. Mamy zatem w tym miejscu punkt styczny, w którym mądrość łączy się z wiarą. Według Pelagiusza do wiary, którą traktuje jako światłość, potrzebna jest mądrość, która w jego ujęciu jest także światłością. Dochodzimy zatem do wniosku, że, według niego, w aspekcie poznawczym wiara i mądrość są sobie równe i wzajemnie się uzupełniają. Należy także zwrócić uwagę na to, że nasz Komentator mówiąc o oświeceniu, przypisuje tę funkcję Duchowi Świętemu ${ }^{46}$, który umacnia wierzących i uzdalnia do poznania bogactwa chwały Chrystusa ${ }^{47}$. Widać

${ }^{42}$ Por. tamże 5, 8, ed. Souter, s. 374 lub PLS 1, 1302-1303: „Quando nesciebatis Domini voluntatem: nunc vero omnia cognovistis. Quantum ergo inter lucem distat et tenebras, tantum a pristina conversatione discrepare debetis".

${ }^{43}$ Pelagiusz stwierdza (por. tamże 3, 18), że mądrość polega na poznaniu wielkości wiedzy. Wiedzę mogą poznać tylko ludzie dobrzy i święci, to znaczy posiadający wiarę. Sądzi bowiem, że mądrość dzięki poznaniu życia wiecznego i piekła daje znajomość i wiedzę potrzebne do dokonania wyboru między dobrem a złem.

${ }^{44}$ Pelagiusz mówi (por. tamże 4, 18, ed. Souter, s. 367 lub PLS 1, 1299) o poganach: „Habent quidem naturaliter intellectum, sed ignorantiae mundanarum sollicitudinum caligine ac tenebris obscuratum [...]. Illi ideo a vita alienati sunt Dei, quia ignorant; vos autem qui cognovistis Deum, sequi debetis". Trzeba też zaznaczyć, że według Pelagiusza (por. tamże 4, 18, ed. Souter, s. 368 lub PLS 1, 1299): „niewiedza zrodziła pogardę dla Boga”.

${ }^{45}$ Pelagiusz komentuje słowa św. Pawła: „Nam fructus lucis est in omni bonitate et iustitia et veritate” (Eph. 5, 9), pisząc: „Talem habet scientia fructum” (por. tamże 5, 9, ed. Souter, s. 374 lub PLS 1, 1303). Za św. Pawłem powtarza, że wiedza posiada owoc światłości, który znajduje się we wszelkiej dobroci, sprawiedliwości i prawdzie. Przyrównując mądrość do światłości, Autor pisze w innych miejscach, że mądrość to światłość, która daje poznanie (por. tamże 4, 18; 5,8) i światłość w Panu (por. tamże 6, 12) oraz, że człowiek dzięki mądrości poznaje Boga i uznaje Jego istnienie (por. tamże 4, 18).

${ }^{46}$ Pelagiusz komentuje słowa św. Pawła: „Ut possitis comprehendere” (Eph 3, 16), pisząc: „Ut ex omni parte magnitudinem scientiae comprehendere valeatis" (por tamże 3, 16, ed. Souter, s. 360). Komentator sądzi, że Duch Święty umacnia wierzących dzięki oświeceniu, które udziela ludziom. Oświeceniem zaś, którym umacnia wierzących jest poznawanie bogactw chwały Chrystusa.

${ }^{47}$ Komentuje słowa św. Pawła (por. tamże 3, 8, ed. Souter, s. 358 lub PLS 1, 1295): „Mihi minimo sanctorum omnium data est gratia haec [...]. Inter gentes evangelizare ininvestigabiles divitias Christi” (Ef 3, 8), pisząc: „Minimo tempore, non labore. Simul notandum quod inter sanctos se humiliando fecerit gradus [...]. Adnuntiare futurae hereditatis divitias repromissas, quas sensus humanus adprehendere nisi revelatione non praevalet" (por. tamże 3, 8, ed. Souter, s. 358-359 lub PLS 1, 1295). Zdaniem Pelagiusza, mądrość zasadza się na poznaniu Objawienia, bo dzięki niemu 
tutaj niejako zaangażowanie całej Trójcy Przenajświętszej w napełnianiu człowieka wiarą i mądrością.

Wyłania się zatem Pelagiuszowa koncepcja chrześcijańskiego życia, która bazuje przede wszystkim na poznaniu Boga, szczególnie Jego mocy i wszechobecności $^{48}$ oraz na naśladowaniu Chrystusa ${ }^{49}$. Komentator podkreśla, że człowiek mądry żyje świadomością obecności Boga, Jego wszechwiedzy i sprawiedliwości. Mówiąc o poznaniu Boga, kładzie szczególny nacisk na poznanie Jezusa Chrystusa, gdyż poznając Chrystusa człowiek doskonali swoje poznanie samego Boga. Przez Objawienie poznaje człowiek mądry także bogactwa chwały Jezusa Chrystusa ${ }^{50}$. Trzeba tu zatem mocno zaakcentować to, że Pelagiusz poznawanie Boga i Chrystusa łączy ściśle z doskonaleniem życia moralnego człowieka.

Autor nasz podkreśla, że dzięki poznaniu woli Pana, człowiek może też poznać hierarchię wartości. Co więcej, zauważa, że człowiek mądry, który poznał wolę Boga, nie będzie grzeszył, ponieważ uniemożliwi mu to wstyd i bojaźń Boża ${ }^{51}$. Natomiast nieznajomość Boga pociąga za sobą brak moralności i człowiek wydaje siebie na pastwę swych pożądliwości, nie zwracając w ogóle uwagi na Boga. To samo stwierdza w odniesieniu do poznania Jezusa Chrystusa. Sądzi, że ten, kto poznał Syna Bożego, nie grzeszy, bo poznanie prawdy o Chrystusie zobowiązuje człowieka do Jego naśladowania i odnowienia swojego życia. Do życia bez grzechu potrzebna jest wiara i mądrość, bo człowiek niemądry błądzi w ciemnościach, pozostaje pod wpływem diabła

wierzący są zdolni poznać przyszłość. Stwierdza zatem, że umysł ludzki nie jest w stanie poznać bogactw przyszłego dziedzictwa, do tego konieczne jest światło Objawienia.

${ }^{48}$ Por. tamże 1, 17, ed. Souter, s. 349 lub PLS 1, 1291. Autor stwierdza, że mądrość daje wyższy stopień poznania Boga, to znaczy poznanie Jego wielkości i mocy. Przez wielkość Boga Pelagiusz rozumie Jego wszechobecność i świadomość tej obecności. Natomiast moc Boża, zdaniem Autora, przejawia się w spełnieniu obietnic, dotyczących nagrody i kary.

${ }^{49}$ Por. tamże 4, 15, ed. Souter, s. 366 lub PLS 1, 1299: „Ut perficiamini in omnibus virtutibus Christi”; tamże 3, 19, ed. Souter, s. 361 lub PLS 1, 1299: „In ipsius perfectionem ex omni parte crescamus”.

${ }^{50}$ Wypowiedzi Pelagiusza o poznaniu Boga przeplatają się z wypowiedziami o poznaniu Chrystusa. Człowiek poznając Jezusa doskonali swoje poznanie Boga. Rzecz znamienna, że Autor ma na uwadze poznanie bogactw chwały Jezusa Chrystusa (por. tamże 3, 16), co dokonuje się drogą Objawienia, bowiem obiecanych bogactw przyszłego dziedzictwa ,umysł ludzki nie jest zdolny poznać jak tylko przez Objawienie" (por. tamże 3, 8, ed. Souter, s. 358 lub PLS 1, 1295). Nie jest jednak nieważna znajomość życia ziemskiego Jezusa, skoro stanowi ona wzór naszego postępowania w świecie doczesnym. Autor zachęca także (por. tamże 6, 10) do naśladowania przykładu Pana i oparcia się o Jego moc.

${ }^{51}$ Por. tamże 1, 17. Pelagiusz sądzi, że świadomość przeżywania obecności Boga wyklucza możliwość grzechu. Jak długo człowiek żyje w obecności Boga, tak długo nie grzeszy. Autor przytacza dwa argumenty. Jednym z nich jest argument rozumowy stwierdzający, że jeżeli obecność ludzi i ich opinia wstrzymują człowieka od niewłaściwego postępowania, to tym bardziej świadomość obecności Boga. Drugim argumentem jest argument z Pisma Świętego: Pelagiusz uważa, że ci, którzy nie znali Boga, nie bali się ani mocy, ani obecności Boga i dopuszczali się grzechów. 
i uwodzony jest przez grzech. W tym kontekście widać powód, dla którego nasz Komentator tak mocny nacisk kładł na naśladowanie Chrystusa ${ }^{52}$, który będąc człowiekiem, ukazał wszystkim ludziom, jaką drogą mają iść przez życie.

Nasz Autor podaje również środki, dzięki którym człowiek będzie mógł doskonalić cnotę mądrości i wiary. Na pierwszym miejscu wylicza czytanie Pisma Świętego ${ }^{53}$, z którego poznaje się wolę Boga i to, co jest dla Niego miłe. Zachęca także do nieustannego obcowania z Bogiem w modlitwie ${ }^{54} \mathrm{i}$ do osobistego uświęcania się ${ }^{55}$, przestrzegając jednocześnie przed niebezpieczeństwem utraty zarówno cnoty wiary, jak i mądrości.

Pelagiusz nie pojmuje mądrości wyłącznie indywidualnie i zaznacza, że ma ona, podobnie jak wiara, aspekt społeczny ${ }^{56}$; uważa, że mądrość objawia się w Kościele szczególnie przez wybranych do pełnienia w nim funkcji przełożonych, wszystkich jednak obarcza odpowiedzialnością za zbawienie lub potępienie innych ${ }^{57}$.

Z powyższego zestawienia najbardziej charakterystycznych cech wiary i mądrości w ujęciu Pelagiusza, wyłaniają się ścisłe związki zachodzące między nimi. Komentator rozpatruje obie cnoty w bezpośrednim i ścisłym powiązaniu z egzystencjalnym życiem człowieka. Człowiek wierzący jest człowiekiem mądrym i na odwrót. Do takiego ujęcia upoważniają nas wypowiedzi Pelagiusza, który kilkakrotnie podkreśla, że, aby stać się wierzącym, potrzebna jest człowiekowi wiedza i światłość Chrystusa oraz życie zgodne z wymogami wiary. I na odwrót, człowiekiem mądrym może być tylko ten, kto ma wiarę w prawdziwego Boga, gdyż to jest warunkiem moralnego i nienagannego postępowania. Obie te cnoty, wiara i mądrość, warunkują prawidłowe odniesienie do Boga.

${ }^{52}$ Autor wzywa (por. tamże 4, 20-21, ed. Souter, s. 368 lub PLS 1, 1300), by chrześcijanie: „Ut, sicut illi, gentili ritu vivatis: ille enim vere Christum audivit et ab ipso didicit, qui in nullo vitio gentibus similis invenitur. Sicut ille vere mortuus est et vere resurrexit, ut nos vere in novitate vitae ambulemus". Uznanie prawdy o Chrystusie zobowiązuje człowieka do odnowienia swojego życia.

${ }^{53}$ Por. tamże 4, 7, ed. Souter, s. 363 lub PLS 1, 1298: „Qui ad quam gratiam se aptaverit, ipsam consequetur: ut puta, qui studiosus legis est, sapientiam, multum orans et ieiunans, eiciendi spiritus potestatem".

${ }^{54}$ Por. tamże 3, 20, ed. Souter, s. 361 lub PLS 1, 1296-1297: „Frequenter maiora tribuit non solum quam petimus, sed etiam quam petere intellegimus, quod ex virtute signorum intellegimus, quae operatur in nobis".

${ }^{55}$ Por. tamże 6, 18, ed. Souter, s. 385 lub PLS 1, 1307: „Sancti estote, ut possitis orare pro sanctis".

${ }^{56}$ Por. tamże 3, 10, ed. Souter, s. 359 lub PLS 1, 1296: „Ut per me his qui rebus caelestibus per omnem Ecclesiam principantur, multiformis Dei sapientia innotescat”.

${ }^{57}$ Por. tamże 5, 15, ed. Souter, s. 375 lub PLS 1, 1303: „Quasi filii sapientiae et lucis, ne alicui offendiculum detis et incipiatis ei causa perditionis exsistere". 
Dowartościowanie mądrości i to tak dalece, że dojrzałą wiarę utożsamia się z mądrością, która decyduje również o przejściu na wiarę - świadczy w pewnej mierze o stoickim podejściu Pelagiusza, który ujmując wiarę w kategoriach mądrości, chciał trafić do współczesnych mu Rzymian, dla których mądrość była zawsze jedną z najwyższych wartości. Pelagiusz uważa też, że istnieje organiczny związek wiary z mądrością. Wiarę traktuje jako dar usprawiedliwiający i zarazem początek chrześcijańskiego życia, mądrość zaś - jako konsekwencję budowania życia na tym fundamencie. Można więc powiedzieć, że wiara jest mądrością chrześcijanina, a mądrość zawsze łączy się z aktem wiary, czyli zawierzenia Panu Bogu.

Te krótkie rozważania stanowią próbę zwrócenia uwagi na wartości poznawcze kryjące się w Komentarzu Pelagiusza do Listu św. Pawła do Efezjan ${ }^{58}$ i uzasadnienia celowości podjęcia jego studium, szczególnie w kręgu studentów teologii. Wydaje się, że istnieje uzasadniona potrzeba prowadzenia dalszych badań analitycznych wszystkich Komentarzy Pelagiusza do Listów św. Pawła, co pozwoliłoby na ustalenia jego nauki o mądrości chrześcijańskiej, zwłaszcza w poszukiwaniu odpowiedzi na pytania o związki tej nauki z cnotą mądrości w ujęciu stoickim.

\section{LA FOI ET LA SAGESSE DANS LA LUMIÈRE DE COMMENTAIRE DE PÉLAGE À L'ÉPÎTRE DE SAINT PAUL AUX ÉPHÉSIENS}

\section{(Résumé)}

Pélage $(† 420)$ dans son Commentaire à l'Épître de saint Paul aux Éphésiens montre qu'il existe une liaison organique entre foi et sagesse. L'auteur traite la foi (fides) comme une sorte de don de départ et à la fois un début de la vie chrétienne. Par contre la sagesse (sapientia) - comme la conséquence de la construction de la vie sur le fondament de la foi. C'est pourquoi on peut dire, que la foi est une sagesse de chrétien et la sagesse toujours se lie avec l'acte de foi, autrement dit croire à Dieu.

La réflexion de Pélage sur la foi et la sagesse enseigne surtout comment entrer au fond des mystères de la révélation qui se trouvent dans 1'Ècriture Sainte. L'appréciation de la foi et aussi si bien que la foi mûre est la sagesse et décision pour aller en foi aussi décide la sagesse - témoigne un peu de stoicisme de Pélage. Pélage qui prend la foi dans la catégorie de la sagesse, a voulu arriver à convaincre dans l'enseignement contemporain Romain. La sagesse pour eux a été toujours une des plus grandes valeurs. L'étude de son Commentaire, oblige à une rèflexion profonde sur l'appréciation dans l'enseignement contemporain, de la problèmatique de la foi et de la sagesse.

${ }^{58}$ W serii „Źródła Myśli Teologicznej” ma się ukazać w niedalekiej przyszłości pierwszy w Polsce pełny przekład Komentarza Pelagiusza do Listów św. Pawła Apostoła. 
